of whom have followed him into the medical profession.

DNL

This obituary first appeared in the British Medical Journal of 29 April 1989 and is reproduced by kind permission of the Editor.

Julius Louis Rowhey, formerly Consultant Psychiatrist, Cassel Hospital, Surrey

Julius Louis Rowley was born in Belfast on 13 March 1911 and educated at the Royal Belfast Academical Institute and Queen's University, where he was awarded both school and university Scholarships and Exhibitions. In 1934 he qualified MBBCh, BAO (Belf) and came to England where he did a variety of medical jobs until 1938 when he went into general practice in an isolated country area until he joined the RAMC in 1940. Here he worked as an officer in a Forward Psychiatric Unit and in Personnel Selection. In 1945 he returned for two years to general practice, this time in an industrial area, and then entered the psychiatric profession. He gained his further psychiatric experience at the Belmont and West Middlesex Hospitals and eventually became part-time consultant psychiatrist at the Cassel Hospital, where he was responsible for much of the inpatient treatment. He was a Foundation Fellow of the College. At the same time he was training at the Institute of Psychoanalysis, being elected an Associate Member of the British Psychoanalytical Society in 1952 and a Full Member in 1955. He became a training analyst in 1956, from 1960-63 was Honorary Training Secretary and from 1963-64 Chairman of the Training Committee. In 1976, he retired from both the National Health Service and his private psychoanalytic practice to live in the country.

He published three papers; 'Two's Company, Three's a Crowd', was stimulated by his experiences at the Cassel. 'Rumpelstiltskin in the Analytic Situation' and 'Rehearsal and Collusion' were based on his interest in words and language, an interest he shared with his analyst, Michael Balint. He was a quiet, receptive analyst but his interventions were always pithy and to the point and he was greatly appreciated by trainees. In his private life, he was very reserved and unassuming, hence difficult to get to know, yet he was also a very kind and helpful person. Unfortunately, like Freud, he was addicted to tobacco and eventually paid the terrible price, dying in 1987 of lung cancer. He leaves a widow, his second wife, the first having died in 1974, and two children, a son and daughter who both live overseas.

\section{Michael Raymond Leahy, formerly Consultant Psychiatrist, St James' University Hospital, Leeds}

It was felt noteworthy in the wake of the death of Dr Richard Wilkie (Psychiatric Bulletin, 13, 396) that Dr Leahy, a Member of the College, suffered the same tragic fate at the hands of one of his patients.

\section{The deaths of the following have also been reported:}

Nenad Bohacek, Professor of Psychiatry, University of Zagreb, Yugoslavia.

Thomas Houston Graham Dick, 32 Augusta Road, Hobart, Tasmania, Australia.

William Vaughan Adams ERSKINE, formerly Consultant Psychiatrist, Garlands Hospital, Cumbria.

SIR ALEC MERRISON, formerly Vice-Chancellor, The University, Bristol.

DAVID MORRIS, Consultant Paediatrician, 24 Wimpole Street, London W1.

JAmes ERnest Runions, Consultant Psychiatrist, University of British Columbia Health Sciences Centre, Vancouver, BC, Canada.

HeInz Hermann OTto WolfF, formerly Consultan' Psychiatrist, The Maudsley Hospital, London SE5. 